\title{
Will the invisible hand fix private higher education in Latin America?
}

\author{
Claudio de Moura Castro ${ }^{a}$ \\ Juan Carlos Navarro ${ }^{b, c}$
}

\section{Abstract}

The essay discusses the strengths and shortcomings of private higher education in Latin America. It argues that private institutions play an important role and shows - with numbers - that profits and quality education are unrelated. In discussing regulations, it argues that both neglect and heavy-handed policies are not producing the expected results. What less prosperous and smaller private institutions need is public support, in order to offer decent quality education and innovate in non-traditional areas, such as post-secondary programs. Indeed, they need help to structure courses, prepare teaching materials and train their teachers. Keywords: Public. Private. Higher education. Universities. Postsecondary education. Liberal arts. Diversification. Technical education. Profits. Quality. Regulation. Accreditation. Authorization. Training of teachers. Teaching materials.

\section{Introduction}

This essay discusses the strengths and shortcomings of private higher education in Latin America. In particular, it questions the ability of less prosperous and smaller private institutions to offer decent quality education and innovate in non-traditional areas, such as short post-secondary programs. It argues that private institutions are welcome at all levels. However, with some exceptions, they need support from the public sector to structure courses, prepare teaching materials and train their teachers.

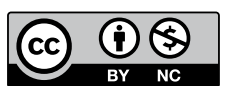

\footnotetext{
Positivo Group (PR). Curitiba, Paraná, Brasil.

b Interamerican Development Bank. Washington, USA.

The opinions and positions expressed in this essay do not necessarily reflect official positions of author's employers.
} 
Higher education - private or public - has a strong public-goods component. Indeed, better-educated people, in addition to their higher productivity, display many other desirable behaviors and traits of character. Therefore it is in the public interest to devise appropriate ways to support this commonly neglected sector. In addition, it saves public budgets that can be used for other purposes.

This discussion is particularly relevant given the ongoing expansion of private higher education all over Latin America, a trend that is likely to become stronger, particularly in a region where secondary education enrollment and graduation rates have been steadily improving ${ }^{1}$.

The essay begins with an overview of higher education in Latin America. Privatization seems to be a trait in countries that are latecomers in higher education. Perhaps, Latin America has pioneered in this expansion. In fact, it displays the same high growth in the private sector observed in Far East nations.

It starts by describing the different types of private institutions. In particular, it focuses on the less visible and prestigious modalities, relatively overlooked in both research and public discussion. At this point, the essay tackles the main preconceptions affecting these institutions, mainly in terms of their quality - whatever that might be. It then examines the profit motive and how it affects institutions. Finally, it reviews public policy towards this group of institutions - which is found to be largely ineffectual, if present at all. It ends by broaching on the rationale for expanding public support for the lower tier of private higher education institutions.

Unfortunately, due to the broad range of countries included in the analysis, some of the statistics are dated and not easy to upgrade. But from all we know, the arguments here presented have not lost their validity in recent years.

As an overiding issue, lies a question mark about the ability of the market to lead to desirable solutions, for those involved and for society. Does the "invisible hand", mysteriously driving market forces, lead to the best of all possible worlds? As argued, this is not always the case. The title of the paper is a reminder of this broad query.

\section{Part of the problem or part of the solution?}

In Latin America, from the eighties on, the responses to rapidly increasing demand for post-secondary education lead to the expansion of existing institutions - sometimes to gigantic proportions. But also to the creation of a whole set of new institutions

\footnotetext{
Curiously, secondary education in Brazil has stagnated in the last few years.
} 
able to accommodate a far more diverse student body and willing to offer entirely new types of academic programs in new institutional settings. To a large extent this was done through a fast expansion of the private sector. As expected, the patterns are quite different depending on the country. In some, as in Brazil, the private overtook public enrollments. By the mid-nineties, the Latin American scene was synthesized as "[...] many more institutions, many more types of institutions and many more private institutions than what the region used to have just a couple of decades ago"2.

Twenty years later, this process, commonly referred to as institutional differentiation, is still in flux and far from settled into a clear and well-defined pattern. There is wide variation in the number or types of institutions, the kind of diplomas they offer, the length of the programs, the type of clientele they serve, the links they establish with government and business or even the names and types of the institutions themselves. In principle, there is nothing wrong with this differentiation.

Public policy addressing the private sector has been as varied as the diversified educational landscape that has emerged. Countries, such as Brazil, have massive regulations at all levels of higher education. Whether they are a help or hindrance is a topic for endless disagreement. In contrast, for a while, Argentina adopted a laissez faire policy towards two-year post-secondary courses.

With so many the new institutions being created, the reaction suspicion clouded the air and, very often, open criticism against their alleged bad quality. Indeed, in some cases, the proliferation of ostensibly inadequate private institutions took place, adding to the general mistrust towards the private sector. The case of El Salvador is a good example. As described by Bernasconi (2008), the country went from having two universities in 1976 to 32 by 1994, an outcome closely linked to lax enforcement of regulations, as a result of political polarization and the civil war ${ }^{3}$.

Yet, it is not only in extreme and idiosyncratic cases that the profit motive is seen as an illegitimate and a poorly veiled force behind the curtain. This, despite the fact that, there is meager evidence to accept or reject such overarching accusations.

To understand this rejection, notice that governments - particularly Ministries of Education - tend to have a higher education staff dominated by former staff from public universities. Given their background, they tend to discount the plights of

\footnotetext{
NAVARRO, J. C. An agenda for research in higher education in Latin America: exploring the consequences of diverse disciplinary perspectives. Cambridge, 1995. [Mimeo].

3 Post-conflict regulation, starting with a new higher education law in 1995, allowed the closing of the most egregious examples of abuse and led to a rapid recovery of the average quality of the system, even though it remains one with high private participation (Bernasconi, 2008).
} 
what they see as lesser institutions. To them, if they are private, at best, they are expected to take care of themselves - the Invisible Hand is expected to sort out problems. In fact, even in public institutions, receiving private funding is seen as incompatible with a publicly-oriented mission. For a number of reasons, the press tends to add fuel to this anti-private bonfire.

This essay attempts to avoid such a priori positions. The fact of the matter is that, both private and public institutions may offer an education of debatable quality.

It is interesting to notice the ideological cleavage in the angry criticism against either system. The right tends to criticize the public institutions, guilty of spending poorly the taxpayers' money. The left criticizes the private "education sharks', as they used to be labeled in Brazil ${ }^{4}$.

Be that as it may, given the public budget restrictions - that are not likely to alleviate in the near future -, it is the private sector that grows faster, just about everywhere. Overall, it is safe to assert that private education is becoming larger ${ }^{5}$.

\section{The growth legacy of the late XXth Century}

From the seventies on, demographic pressures have been driving basic education systems in Latin America, creating a rapidly expanding demand for tertiary education. This is a classic situation: The more students finish secondary, the greater the pressure to expand enrollment in higher education. Since the graduates, at least initially, are predominantly from the middle classes, their ability to translate this demand into political pressure is well known. And, one way or another, governments yield to the pressure.

This led to substantial expansion in the supply of higher education. The pressures were, at the same time, so uniformly strong that differences in political savvy and strategy in dealing with the issue across countries produced outcomes different only in the degree, but not in the nature of the transformations of higher education.

In all countries, the systems of higher education expanded, sometimes more than doubling their sizes. Everywhere, entirely new breeds of institutions appeared: technological institutes, university colleges or other institutions providing shorter

\footnotetext{
4 Ideological cleavages are far from over. Witness the debate on higher education reform in Chile, during the second Bachelet administration. in which all the arguments, briefly described above, have gained ample public currency.

5 In Brazil, the private/public proportion has stabilized around $75 \%$ of enrollment.
} 
courses. In all cases, private institutions have been a large part of the expansion, both in enrollments and in diversity. Chile went from 8 institutions of higher education - all universities - in 1980 to 163 institutions of higher education in 2010 (all but 16 are private), with enrollments multiplied by 5 over the same time span. Mexico went from 225 institutions in 1980 to over 2,000 by 2010, more than tripling enrollments during this period, one third of which corresponded to private institutions. Brazil started expanding somewhat earlier, with private enrollments doubling during the seventies, reaching 58 percent in 1994 and then reaching 75 percent in recent years. Similar stories could be told of other countries, with some Central American nations also experiencing a large growth of the private sector in the early nineties. Venezuela went from 6 percent of total enrollments in private institution in 1970 to twice that proportion by 1980 and then to 35 percent in the early nineties, only to see that share decline slightly to 28 percent, after a vigorous expansion of public institutions in the early 2000s. Only Venezuela, Paraguay and Colombia have experienced faster growth in public enrollments from 2005 on $^{6}$.

Even though many of the new institutions were universities, in most countries, entirely new types of non-university institutions made their appearance, starting in the seventies. And they grew significantly, often at a faster pace than the system as a whole. The outcome was an increasing diversification of higher education systems, a trend that was already consolidated by the end of the XXth century and has not been reversed anywhere ever since ${ }^{7}$. The fiscal difficulties, typical of Latin American governments in the period, seem to be a powerful reason for this pattern. But variations in policies produced some diversity within the boundaries of the general trends that have been sketched.

At this juncture, we need to clarify some confusion in names. Post-secondary programs lasting between two and three years have a wide variety of titles in Spanish and Portuguese, depending on the country: "University colleges", "Technological Institutes" and many others. They stand as clearly distinct from the traditional diplomas earned in programs that last between 4 and 5 years. For the sake of this article, we will refer to these shorter degrees as "non-university tertiary institutions" (NUI) ${ }^{8}$.

\footnotetext{
6 Data on shares of private enrollments from UIS database, are from February 2016. Data on number and sector of institutions and overall enrollment trends come from Brunner and Ferrada (2011).

7 The fact that diversification has become a well-established reality in Latin American higher education, by no means implies that public policy has taken full and adequate account of its implications.

8 More formally, the degrees offered by NUI square with the official Unesco definition of Isced 5B (for International Standard Classification of Education), understood as study programs that are "[...] generally more practical/technical/occupationally specific that ISCED 5A programs" (conventional university diplomas, CdMC-JCN). They typically take between 2 an 3 years to be completed (UNESCO, 2010).
} 
There is one critical difference within this group. The issue is whether they are legally considered as "higher education", something that is not always the case in the official classifications. If they are, in addition to a status premium, they may allow access to other higher education programs. To illustrate, the Brazilian Tecnólogo is higher education, hence, graduates can apply to master programs. In contrast, the shorter Ensino Técnico is not higher education.

However, when we come to the regular 4-5 year programs, the differences within are also a bit baffling. Everybody would like to boast the epithet "university", with all the status that still comes with it. But in different countries, the criteria to use the name are considerably different. Brazil has the toughest access ramp. Simplifying, to become a Universidade, the institution must have at least three Master Programs and one Doctorate, all of them with decent evaluations in the rigid Capes system.

The growth of regulations and regulatory agencies for authorization, accreditation and granting the status of University has been uneven but steady across Latin America. In a few countries, it has been quite easy to become a university. However, private abuses and poor public policy and planning have led to a reversal of these "free-for-all" policies, leading to the emergence of more stringent regulations 9 . The trend has been moving in the direction of ever more structured processes and criteria applied to the labeling of institutions as universities, with a few exceptions ${ }^{10}$.

The criteria, however, remain highly variable from country to country and a degree of unpredictability survives in their application. As a general rule, "universities" have a broader menu of courses. But all these terms should be used with due care, so as not to confuse the traditional four-year programs, whether called university or not, with the newer generation of short careers. Be that as it may, in most countries, Universities are more prestigious and affluent than the other categories.

Above all, there is no intrinsic reason why teaching and learning in a University should be better than that in another that does not sport that tittle. The correlation between words and reality tends to be weak. Indeed, differences in classification seem to have only a modest correlation with quality, if at all. Table 1 depicts the

\footnotetext{
9 See the El Salvador's case commented above. But it is easy to find similarly oriented if less extreme cases of improved regulation of licensing and accreditation across the region. A recent case in point can be observed in the recent higher education reform in Ecuador (Guaipatín; Schwartz, 2014).

${ }^{10}$ An example of regulations being relaxed can be found in the case of Venezuela under the Chavez administrations. The expansion in public enrollments previously alluded to in this essay, in the early years of the new Century, was mainly the result of the creation of two massive public universities accomodating over 100,000 students each, built with little regard for existing licensing and accreditation rules. In the meantime, the public agencies in charge of defining and enforcing regulations were severely weakened. For a recent account of the process see Albornoz (2014).
} 
Table 1. Relative shares of private enrollments and institutions in selected higher education systems in Latin America, 1994 and 2010.

\begin{tabular}{lcccccccc}
\hline & \multicolumn{2}{c}{ Enrollments 1994 } & \multicolumn{2}{c}{ Enrollments 2010 } & Institutions 1994 & \multicolumn{2}{l}{ Institutions 2010 } \\
\cline { 2 - 9 } Country & Total & $\begin{array}{c}\text { Share } \\
\text { in (\%) }\end{array}$ & Total & $\begin{array}{c}\text { Share } \\
\text { in (\%) }\end{array}$ & Total & $\begin{array}{c}\text { Share } \\
\text { in (\%) }\end{array}$ & Total & $\begin{array}{c}\text { Share } \\
\text { in (\%) }\end{array}$ \\
\cline { 2 - 9 } & Private & $\begin{array}{c}\text { Total } \\
\text { H.E. }\end{array}$ & Private & $\begin{array}{c}\text { Total } \\
\text { H.E. }\end{array}$ & Private & $\begin{array}{c}\text { Total } \\
\text { H.E. }\end{array}$ & Private & $\begin{array}{c}\text { Total } \\
\text { H.E. }\end{array}$ \\
\hline Argentina & 213,904 & 20.00 & 644,49 & 27.00 & 760 & 43.35 & 1,235 & 55.96 \\
Brazil & 970,602 & 58.00 & $4,783,690$ & 73.00 & 633 & 74.38 & 2,212 & 95.59 \\
Chile & 175,514 & 54.00 & 700,8 & 80.00 & 245 & 90.74 & 147 & 90.18 \\
Colombia & 359,991 & 64.00 & 753,3 & 45.00 & 179 & 69.38 & 284 & 75.73 \\
Mexico & 329,047 & 25.00 & 911,04 & 32.00 & 248 & 37.01 & 2,135 & 78.67 \\
Peru & 231,084 & 36.00 & 651,78 & 54.00 & 302 & 44.61 & 261 & 21.39 \\
Venezuela & 213,939 & 36.00 & 615,67 & 29.00 & 54 & 47.37 & 95 & 55.88 \\
Total & $2,494,081$ & - & $9,060,770$ & - & 2,421 & - & 6,369 & - \\
\hline
\end{tabular}

Source: For enrollments, 1994, García Guadilla (1997), 2010, Unesco (2012). For institutions, 1994, García Guadilla (1997), for 2010, Brunner and Villalobos (2014).

officially given distribution of the two categories of institutions, shedding some light on the broad picture of higher education.

As it can be seen in Table 1, by 1994, in terms of enrollments, private institutions already constituted a sizable proportion of higher education in all the countries considered. Yet, in the 15 years that followed, the expansion of private enrollments, far from stabilizing, continued at an unrelentingly fast pace. By 2010, private enrollments had more than tripled across all the systems considered, and this led to an expansion of the relative share of enrollments in 5 out of 7 countries. Peru represents the exception, due mostly to a proliferation of regional public teaching colleges.

Table 2, in turn, looks in more detail at the evolution of enrollments in NUI in four countries. As it can be observed, the share of NUI enrollments in total private enrollments is high and growing in all cases, unless Chile can be counted as an exception, for going from 100 percent (all NUI in the private sector in 1994) to $94.4 \%$ in 2010 . If there is a generalization to be made, it would be that, in Latin America, a substantial majority of private students are enrolled in non-university higher education institutions, and most are private ${ }^{11}$.

${ }^{11}$ A clearer exception is Mexico (not included in the table, given difficulties in obtaining recent data), where a strong governmental support for higher education has never faltered, and non-university tertiary education has been kept mainly public. 
Table 2. Share of Non-University Tertiary enrollments in total private higher education enrollments in Latin America, 1994-2010. Selected countries.

\begin{tabular}{lcc}
\hline \multirow{2}{*}{ Country } & \multicolumn{1}{c}{ Share of NUI enrollments in the private sector (\%) } \\
\cline { 2 - 3 } & $\mathbf{1 9 9 4}$ & $\mathbf{2 0 1 0}$ \\
\hline Argentina & 28.67 & 41.00 \\
Brazil & 81.03 & 85.20 \\
Chile & 100 & 94.40 \\
Peru & 36.70 & 67.60 \\
\hline
\end{tabular}

Source: For 1994, García Guadilla, 1997. For 2010, Unesco, 2012.

\section{The different faces of private higher education}

Beyond the general picture that can be drawn from the figures presented above, how do private institutions of higher education in Latin America look like? On this, an early appraisal from Balán and García de Fanelli (1997) concluded, in way that is still worth quoting at length:

[...] even if it is impossible to generalize for all cases, we can construct two "ideal types" of the private sector: elite and excess demand accommodating institutions. Private sector elite institutions have an intermediate size and are concentrated in the most developed regions in a country. They offer a relatively wide spectrum of degrees at the university level, primarily in the social sciences, and only exceptionally in areas like health care or natural sciences. Their activity has been mainly teaching but they are moving into graduate studies and research activities, with some financial support from the public sector. In order to carry out these activities, they have a faculty of comparable level as the public sector, even though they tend to be short of full time professors. Among other factors, their high tuition fees dictate that their clientele comes from upper and upper-middle income groups. The private sector institutions that accommodate excess demand are relatively small and, even though they also tend to be concentrated in the most economically developed areas, they have, when they offer non-university courses, some wider presence in other regions of their countries. They carry out their teaching activities in low cost disciplines (mainly social sciences) and in professional tracks in line with labor market conditions and the corresponding demand for higher-level credentials. They develop neither graduate programs nor research and the faculty is part-time, normally hired on a per/hour basis, offering evening courses adapted 
to a lower-middle class clientele that study while keeping their day jobs. Accordingly, they tend to have low tuition fees, and pay less well to their faculty (p. 32, Translation JCN).

There was little to dispute regarding these two "ideal types". However, they subsume an early pattern of development. Today, we have to go beyond this dichotomy of first vs. second tier institutions and pass a finer comb through the highly heterogeneous group of private institutions ${ }^{12}$.

\subsection{The classic elite private institutions}

The classical model of the "catholic university" epitomizes the ranks of the first tier. However, in recent decades a few technically-oriented elite institutions have emerged. The Tecnológico de Monterrey is an outstanding example. Institutions such as the UTEC and UTP in Peru have smaller size but comparable ambitions and potential.

One first important addition to the new list would be a quantitatively small but intellectually and politically important group of top-level research think tanks, as well as independent management and public-policy schools. They may play a salient role in quite a few countries, as sources of policy analysis and places for training the managerial, intellectual and, increasingly, public sector elite. Incae, Torcuato di Tella, El Colegio de México, Getúlio Vargas, Iuperj, Insper, Fundação Dom Cabral, IESA, Ilades and others have built an admirable niche in higher education systems, for missions that are, at the same time, socially useful and academically relevant. They are private institutions, but very often bid for research funds from government agencies (not differently from the American private universities). This "ideal type", in all its modalities, has been the subject of a major research effort by Levy (1996).

\subsection{High-end post-secondary technical schools}

Other interesting initiatives are the post-secondary programs of the Brazilian Senai, combining state-of-the-art technical education with R\&D and technical assistance to enterprises. Most of these schools offer vocational training, two-year postsecondary programs, skip undergraduate degrees and operate non-degree post-graduate programs. They are private institutions, belonging to the Federations

\footnotetext{
${ }^{12}$ The following discussion runs close to that of the an IDB's strategy for higher education published in the late nineties (BANCO INTERAMERICANO DE DESARROLLO. Argentina: Programa de reforma de la educación superior no universitaria. Washington, DC, 1997. [Mimeo].), where, for analytical purposes, a distinction was established among four functions of higher education institutions in the region: academic leadership, professional work, technical training and development, and general higher education.
} 
of Industries and funded from a levy on the payroll - in that sense, they are not pure bred private institutions. Be that as it may, they are very important as bellwethers of a new line of technical institutions very closely connected to industry and targeting specific industries, rather than following the more common "polytechnic" model. Rather than schools preparing labor for the market at large, they are technical centers to support enterprises, with a wide range of services in which technical courses are one of the offerings.

\subsection{Conventional new privates}

Once we move away from these elite schools, we will find a group that is very heterogeneous but not necessarily less affluent. Inside this disjointed second-tier group we probably want to distinguish two major categories.

The first is a very large group including the more common and conventional schools (and universities) that mimic the traditional elite universities in their curricula and intentions. They offer the same traditional courses in Education, Economics, Business, Law and most other "chalk and talk" careers. However, in Brazil, responding to the economic boom starting around year 2000, engineering education today enrolls more students than Law.

Due to their modest endowment and means, as well as the lower academic abilities of the students, their graduates are rarely counted amongst those who find jobs corresponding to the words that describe their diplomas. Given the explosive expansion in these careers, there are many times more graduates than jobs. Therefore, few manage to get them. Obviously, the small share of graduates who land in these few jobs tend to be the graduates of the elite institutions (public or private). The remaining find jobs but they take up occupations that do not require a specific professional diploma. Their market is the vast collection of occupations in the service sector or in the service end of the manufacturing sector. They are the typical office occupations, dealing with the endless varieties of buying, selling, organizing and managing.

This occupational drift is by no means a dysfunction or a distortion in Latin American markets or education. It happens in all mature economies, where a large proportion of higher education students end up in these loosely defined occupations, regardless of the diploma they hold. The fundamental difference is that, in Anglo-Saxon countries, graduates of the, so-called, Liberal Arts schools are not expected to find jobs corresponding to their diplomas. They do not harbor any hopes or desire of becoming Medieval Historians or experts in Greek Philosophy. Their curricula explicitly recognize the "general education" 
nature of what they studied. In fact, the American expression "major" conveys the idea that these courses are not a preparation for specific occupations to be found after graduation.

The problem with the Latin American version of these "deprofessionalized professional schools" is twofold. First, it disappoints students and creates frustrations, to the extent that many students feel that something is wrong when they cannot find a job titled with the same root as that describing their diploma (economics/ economist).

The second problem is that these courses are less than ideal for the majority of the students who may lack the academic profile required for a highly theoretical curricula and the lack of connection between education and jobs.

There is a mismatch between the highly abstract and theoretical material contained in the curricula and the low capacity for abstraction of the students, victims of low quality K12 education. The abstractions in Economics, to cite an example, are particularly removed from everyday life and the teachers tend to be unable to bridge this gap. Management tends to be a succession of techniques/theories that are never applied in concrete examples during the course of studies. Rarified pedagogical theories are hardly understandable.

Curricula are not appropriate, even for the purpose of developing analytical skills, because they are too removed from what makes sense to the students. This is made worse by the lack of practical applications.

Is all that useless to the less-prepared students? Not quite; four years listening to classes, reading books and writing answers or essays is far better than the complete dearth of intellectual stimuli that behooves on those who get simple jobs. But the proof of the pudding is the fact that salaries of the higher educated are higher, demonstrating that they are better prepared to learn along their professional lives ${ }^{13}$.

The point is not that the courses are useless, but that these four years could be far better used. To wit, less taxonomies to memorize and less stratospheric theories would be welcome. The students need more practical tasks along the course of studies. More writing. More books to read. The recipe to improve is not overwhelming. However, nothing much seems to happen along these lines. Since top schools have plenty of theories, the others mimic their models. Few escape from this curse.

${ }^{13}$ In Brazil, higher education graduates still earn more than twice as those with only a secondary diploma. 


\subsection{Open capital private institutions}

In addition to the types of private institutions described so far, Brazil has witnessed in the last decade the surprising appearance of a new institutional model of higher education, one that is worth examining in detail, in the context of this discussion. Successful private institutions, investment banks, foreign venture capital funds and other sources have pulled together to buy higher education institutions of all sizes. As a consequence of successive consolidation of small and mid-sized colleges, huge institutions have been born. A few have over one hundred thousand students. Presently, one of them has more than one million.

In the early years of the new Millennium, Brazilian officers of the Ministry of Education, as well as the left, feared a takeover by the aggressive American forprofit universities. One Minister proposed restrictive laws against the presence of foreign "capitalists" in the sector (but nothing came of it, since it was part of a broader legislation that met fierce opposition). Ironically, this wave of internationalization did not happen, even though some American institutions came and purchased several private four-year colleges. Why the roar of the lion was not followed by carnage? Mostly, for two reasons. The first is that there are not that many such private for-profit institutions around the world. They are either American or Australian. The latter are geographically too removed and busy with the Far East markets. Big American institutions are no more than three or four (Phoenix, Laureate and DeVries are the largest and already in the country).

The second reason is that aggressive Brazilian capitalism moved faster and occupied the market. Some brought in foreign venture capital. But while these funds might invest in Education, they have no particular expertise or interest in the area. Therefore, they bring funds, audit the accounting and do little more. In matters of Education, they show no interest.

When we look at the management teams of such behemoths, they come from modern business, aggressive investment banks and a few education entrepreneurs, mostly engineers who created large, multi-campus K-12 schools. Their accounting and auditing performance is superlative. They use modern management tools and have deep pockets. In contrast, thus far, they have done little to change classrooms and teaching styles. In the last few years, they have been preparing to bring technology to classrooms. But, there is still too little to show. What about the quality of the teaching offered? This topic will be covered in a subsequent part of this essay. For the moment, it suffices to say that they are neither better nor worse than the other private institutions ${ }^{14}$.

\footnotetext{
${ }^{14}$ A detailed account of this process in the case of Brazil can be read in Sampaio (2014).
} 


\subsection{Short programs with different names}

The last and the most problem-riddled category of second tier private institutions is made up by the fuzzy and ill-defined technical short careers, here referred to as NUI. In many ways, there is a huge unfulfilled potential in these programs - as illustrated by what happens in the industrialized world. Most of these courses cater to technical careers that previously were offered at secondary level. Until recently, they did not exist at all. They issue diplomas as technologists, associate degrees, operational engineering or whatever other term is fashionable at the moment. They are sometimes reluctantly accepted as higher education. Administratively, they belong to the "post-secondary" or "non-university tertiary" limbo.

One major shortcoming of these programs is that they suffer from "miniaturization", which is the practice of merely shrinking courses in engineering programs into two or three years. This has clearly happened in Argentina and Brazil. The unavoidable result of this diet is that most programs end up weak in theory and weak in practice.

This essay contends that NUIs are the number one problem in the lower tier private education. These are the less prosperous and less sophisticated of all higher education institutions. And their students belong to the lowest social strata to reach higher education. Since they are seen primarily as second - or third - best substitutes for university education, they become, by default, the pick of last resort for any prospective student. Worse, they get little respect from society and little support from the government.

Latin American short careers, from a public policy standpoint, are important for many reasons. The fact that they have emerged, multiplied and sometimes prospered - at least quantitatively - shows that they are not going against the grain of the market and can play an important role in preparing labor. Yet, there are no reasons to believe that market forces are generating or will generate good models. In fact, as will be argued below, market forces, even under competitive conditions, have been incapable of producing a good third-tier system of private education.

\section{The quality controversies: are the privates that bad?}

As it was mentioned, Balán and García de Fanelli's ideal type for the second tier institutions depicts the typical private institution in this category (1997). They are small, primarily concentrated in the most economically developed regions and operating in low cost disciplines (management and social sciences, in general). They rely on part-time faculty and cater to a lower-middle class clientele, in addition to having, at least, some loose connection to labor markets. We briefly discuss below the transformation that took place in these institutions. 


\section{Costs and quality}

In most countries, private institutions have lower unit costs, compared to the publics - of course, there are also the expensive elite private schools. In fact, tuition levels must be affordable by their lower middle-class students, mixed with some working class enrollment. In Venezuela, unit costs of private universities are about one third of public universities. In Brazil, the proportions are approximately the same. The private cost advantage also exists in the case of four-year colleges, but the gap is far less pronounced.

This difference has been usually attributed to the lack of research in the privates, but in the cases described, the comparison has been careful to take only instructional costs in public universities. Notice also that very few publics do research. Other common explanations for the low costs of private institutions point at the intensive use of part-time faculty. That, mind you, is not different from what American Community Colleges do.

The concentration of the academic courses in the social sciences, which do not require the expensive laboratories of natural sciences and engineering, is claimed as another reason for the difference. This is indeed very much the case. But there is another side to this story, which is the advantage of being free from civil service rules and teacher unions that affect public institutions. All this has been well established in the literature for quite some time: Sanfuentes (1990) described a consistent pattern of lean administrative staffs in Chilean private tertiary institutions, which seems to be consistent with information from Brazil's private sector (TRAMONTIN; BRAGA, 1984), as well as from Venezuela (BRUNNER; WOLFF, 1992). These findings remain unchallenged and valid today.

The fact that the costs are low leads directly to the discussions about quality. From the very beginning, there has been an issue on whether low costs are an indication of healthy administration and internal efficiency or rather the sign of an unavoidable low quality. Let us consider the facts. First, it is important to realize that the world is bound to be a mixed bag. Some private institutions produce graduates that compete successfully in the market with the graduates from traditional institutions. If they do that at lower costs, then efficiency is clearly the right answer. In addition, earnings functions typically show that degrees from these institutions have a significant market value (even if generally not as high as a top university degree). This seems to imply at least a minimum of value added in the education offered by these institutions.

The most common piece of evidence brought to bear in this argument about the poor quality of private establishments is their heavy reliance on part time 
faculty, as opposed to the development of a full time professorial body, typical of richer institutions. Surely, the use of part time professors may be dictated by economic considerations. But, as Cox (1990) has argued, it is not clear at all that a full time faculty is the right solution to the kind of education that these private institutions intend to offer. Highly experienced practitioners, in close contact with the day to day requirements of the market, can be far more suitable for a clientele expecting a quick insertion in jobs, compared to traditional professors who have a hard time getting close enough to what works and what is useful in the real world ${ }^{15}$.

Thus, the public-private divide is clearly not a quality divide in many countries. If reputation is a guide, countries seem to be all over the place when it comes to the relative prestige of private vs. public. Public opinion, in some countries, clearly consider the private institutions as better than the ostensibly mismanaged and underfunded public. Yet, in others, the opinion goes exactly in the opposite direction. Hard evidence, on these matters is very hard to come by ${ }^{16}$.

For the moment, it suffices to state that any automatic and general assimilation of private education with suspicious academics or low quality must be dismissed. Poor higher education quality can afflict both public and private institutions, depending on the time, place and circumstances. Indeed, good quality and excellence is not the monopoly of either sector.

\section{The profit motive}

Closely linked to the quality debate, has been the issue of the profit motive, supposedly guilty of much of what is wrong or evil with some of the private tertiary institutions. No doubt, there is no shortage of unscrupulous operators exploiting the information asymmetries, typically present in the market for education services. The folklore is abundant.

The non-profit status of most private establishments leads to practices of disguised distribution of profits, a phenomenon common to Latin America and other parts of the world. Some institutions charge a high tuition and offer very little value for the money. The owners distribute the profits as high salaries for the executives and perks. Also common are mechanisms to outsource, at high costs, services

\footnotetext{
${ }^{15}$ As will be fully demonstrated in the next section, Brazilian data provide a very robust support for this hypothesis.

${ }^{16}$ A potentially major source of data, the OECD-originated Ahelo (Assessment of Higher Education Learning Outcomes) project, was discontinued in 2015, after a technically and substantively promising test run. Its ambition of developing standardized measurements of education quality for higher education programs - a PISA for higher education, to some extent - was left without support from most of the leading universities of the world.
} 
such as janitorial or computing, to private firms belonging to the owner of the school. All of this really happens. In some cases, there is hard data, in others, one can find believable but not rigorous evidence.

On the positive side, there is evidence that quite a few private institutions have invested their earning from tuition to improve infrastructure, a fact clearly documented in the case of Chile (SANFUENTES, 1990), but far from restricted to that country. In the case of Brazil, before 1995, higher education was not allowed to show profits (and pay taxes). Hence, private institutions tended to invest heavily in physical facilities, in order to absorb the surplus revenues ${ }^{17}$. The recent boom in private higher education in Peru, includes some examples of rather humble private institutions - such as the TECSUP-UTP - that have found a growth strategy closely linking academic excellence, relevance for the local economy and investment in infrastructure. It seems only logical that attractive buildings and facilities make institutions more desirable to students. But this is not necessarily at the expense of quality education. Having a nice physical environment may be a good investment to increase enrollments ${ }^{18}$.

Infrastructure is, on the other hand, only one of several paths traveled by private institutions in their relentless search for respectability. In countries where this is allowed, probably the most common gimmick is the adoption of the label "university", regardless of any consideration for what it might mean. It is believed that much of the suspicion will subside, just because the name of the establishment is changed.

There are still other paths, such as the hiring of a few star professors retiring from traditional universities, in order to establish a small but top level research and doctoral unit in a narrow field, which stands in stark contrasts with the mass production of certificates in the rest of the institution. However, the hard facts of costs make this the only viable solution for quality graduate studies in private education. An academic Master or Doctorate costs far more than students can afford to pay. Therefore, in order to have good programs, they must be limited and the deficits funded from the revenues of a large undergraduate enrollment. While there is nothing wrong with this solution, there is scant, if any, evidence that these programs will have

\footnotetext{
${ }^{17}$ In the case of Brazil, in which hard data are available, the correlation between the quality of facilities and quality of teaching is not significant.

${ }^{18}$ This is not to say that inadequate infrastructures is not a problem. A study conducted for the preparation of an Inter-American Development Bank loan in Argentina in the nineties determined that in $80 \%$ of NUls, out of which half were privates, facilities where shared by two institutions or with other levels of education. In addition, 35 percent or the private NUIs had poor facilities, libraries were insufficient and poorly stocked, laboratory equipment was obsolete and teaching materials inadequate (BANCO INTERAMERICANO DE DESARROLLO. Argentina: Programa de reforma de la educación superior no universitaria. Washington, DC, 1997. [Mimeo].).
} 
any positive impact on the teaching quality at the undergraduate leve $\mathrm{l}^{19}$. They may bring prestige and attract better students but do not improve teaching.

All in all, a general description of the quality of private mass education is quite elusive. First of all, this is a highly heterogeneous group. Secondly, private higher education is in flow, many changes have taken place and more are coming.

In the remaining of this section, we explore the theme of profits and private ownership in higher education from an empirical perspective. Concretely, what do the numbers tell about profits and the resulting quality of the education offered? If for-profit institutions cannot provide quality education, we need to worry, considering their growth in the recent past. But if it turns out that profits do not harm quality, what can be wrong with it?

Brazil constitutes the obvious case study because reliable and universal measures of school achievement exist for graduates of four-year programs. No other country has such indicators. In the mid-90s, the Ministry of Education created what was then called the provão, a test applied to graduating students, covering the core subjects in each career. Mean results for each institution are transformed into a grade. The system has gone up and down but it remains in place and yields very useful and powerful results. The grades for courses and institution are readily available at the Internet - a unique case in Latin America and elsewhere.

Despite some imperfections and unresolved technical issues in the tests, they provide a way to determine how much of the curricula students from different schools have mastered. The tests are professionally prepared and, certainly, far better than what teachers use to grade students and determine whether they reach the levels required for graduation. Overall, they generate very robust numbers.

The first question answered by the data, in the context of our discussion here, concerns the relation between private ownership, profits and academic performance of students in each category. One of the authors undertook an analysis of a modified version of the original data basis and the results are summarized below. We begin by comparing public universities (most are Federal), private not-forprofit institutions, regular for-profits and a fourth and new category. Beginning in the year 2003, some of the bigger schools partnered with banks to open their capital (in technical jargon, to made Initial Public Offerings, or IPOs). As of this

\footnotetext{
${ }^{19}$ A lack of recognition of the necessary diversity of institutional missions across the higher education systems has led in some cases to make scientific research mandatory for all institutions, forcing universities that should be focused on the improvement of teaching to spend significant resources in one or two particular lines of research, with only the weakest of links with the core activities and mission of the institution.
} 
day, four have offered IPOs. Since they have been aggressively buying small and large institutions, in order to grow fast, the figures for programs belonging to institutions with IPOs had reached 23 at the time the data were collected (2009). Hence, the fourth category is "open capital for-profit institution". The numbers confirm some assumptions but destroy a few myths (Graph).

Just about everybody proclaims the vast superiority of public over private institutions. The reality is not as black and white. As the numbers show, the mean scores of the public sector are somewhat higher. However, one cannot simply say that the public institutions are good and the private ones bad, because there is much overlap between the two curves. Indeed, the difference between means is quite modest, suggesting that the categories are more equal than different. The accompanying box diagram summarizes the numbers (the top and bottom lines in each box represent, respectively, the means of the top and bottom quartile. The wider apart they are, the greater the variance).

Contrary to expectations, the public sector is just as heterogeneous as the private. Even more surprising, some public universities can be quite weak. There are more top quality institutions in the public sector but the bad ones are just as bad as the bad ones in the private sector. In other words, being public is no insurance against poor quality.

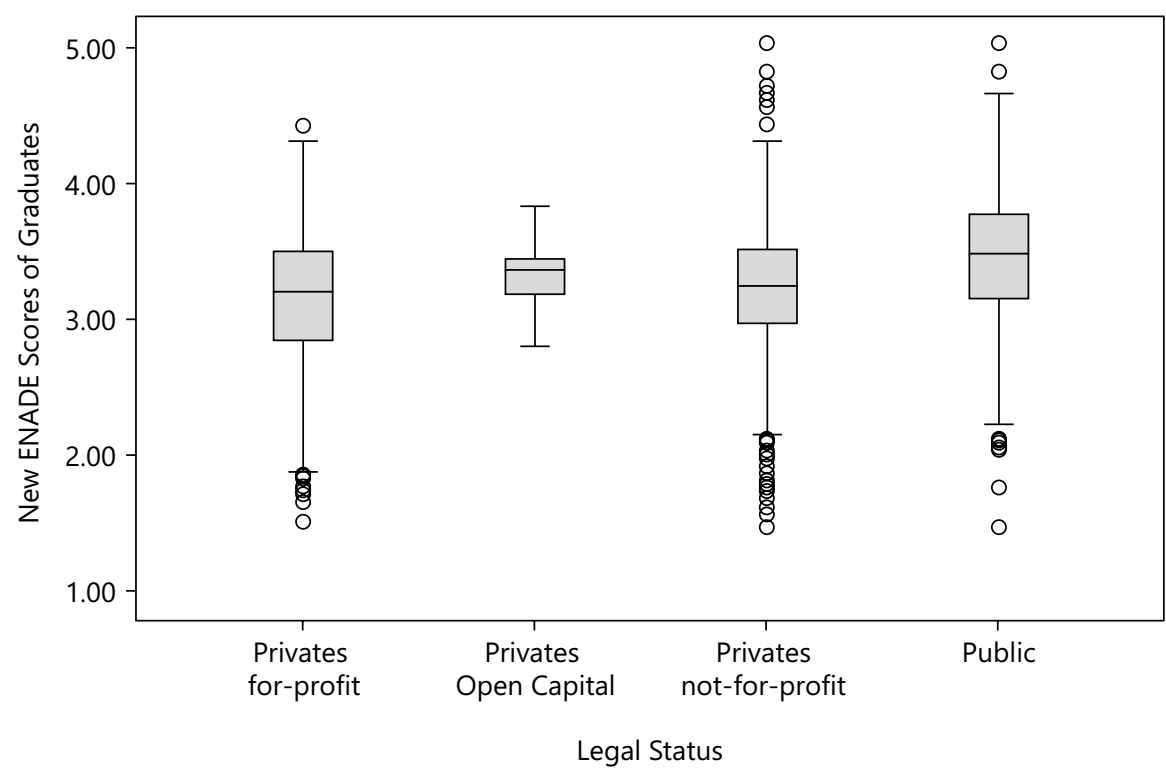

Graph. Performance distribution of different modalities of higher education according to the "New Enade" indicator. 
In addition, even though the public institutions have somewhat higher means, both the private for-profits and the not-for-profits also have some outstanding examples of quality education.

Perhaps the single most surprising results come from comparing the three types of private institutions. As we can see, the scores are quite close. In fact, the differences are immaterial. For all practical purposes, the profit motive does not hurt significantly the quality of education. Why would that be? Whatever the reasons, the data show clearly that declaring a profit motive is unrelated to academic quality.

Looking now at those that have had IPOs, we also find that the performance of their students is not inferior. Surprise! In fact, they show an ever-so-slight superiority to others from the private sector. The proximity to bankers and their rates of return is not so deleterious to education, after all. These results put to rest the "holier-than-thou" attitudes of some philanthropic institutions, sneering at their for-profit and IPO counterparts. Whatever the inner logic of open capital institutions, it is clear that, on average, it does not hurt quality.

However, the curves also show that IPOs institutions are a different breed. While their mean scores are insignificantly better, the variance between the schools is much smaller. They do not inhabit the high end of the distribution. But even more striking, they are a much more homogenous group with no truly weak institutions among them.

In fact, their weakest programs are less weak than some public universities. It appears that their internal rules have been more effective in prunning the bad apples. However, some rules also prevent them from rising above levels that remain quite modest.

We can also use the data to correlate academic achievement with quality of infrastructure, proportion of faculty on full-time contracts, proportion of teachers with Master Degrees and the proportion of teachers with Doctorates. The results are no less striking. To make a long story short, none of these four indicators show any significant correlation with academic quality. In other words, students do not learn more in institutions with a higher proportion of Masters or Doctors. Also, more full-time faculty does not bring any academic advantage.

We could spend endless pages trying to explain such results. What matters is that they break several myths. Whether we can extrapolate them to the 
rest of Latin American is an open question ${ }^{20}$. In principle, it would not be prudent. But we are facing robust conclusions drawn from a system with about seven million students and three thousand institutions - at the time of the dataset. In addition, we are not dealing with samples, but with the universe of higher education.

\section{Can the private schools lift themselves by their bootstraps?}

Previous sections have suggested that public policy regarding regulation of the private sector is evolving.

But there are indications that it is far from uniformly beneficial in its effects across the region. NUI seems to be a particularly notorious blind spot when it comes to public policy. As it was suggested before, at best, the record of public intervention is mixed. It is not at all clear that is has helped more than it has hindered. Surely, the role of controls is very different from country to country. Therefore, any generalization is perilous.

To a large extent, public policy regarding private institutions has either taken a laissez faire attitude or controlled initial authorizations to operate. Controls along the way are less common, although they are becoming part of the mainstream, through the development of accreditation systems in many countries of Latin America over the past 20 years. Some of the most frequently traveled paths for public policy have been:

a) Allowing quick licensing of new institutions. Earlier, Argentina (until the eighties) is a good example of an unsuccessful policy.

b) Making it hard to obtain initial authorization, but then forgetting about controls, once licensing is completed. This happened in Brazil.

c) Founding a substantial number of public NUIs but allowing them to deteriorate, becoming hard to distinguish from their private counterparts. Venezuela and Mexico can make good cases.

\footnotetext{
${ }^{20}$ In a recent analysis of the Chilean case (URZUA, 2012), rates of return to education in different types of higher education institutions are consistent with the conclusions drawn from the Brazilian data. As it turns out, 35 five per cent of students enrolled in top tier and traditional public universities have a negative return to their investment in higher education studies, while the figure for private institutions is about 40 per cent. Even if this analysis is not using a direct measure of education quality, on the reasonable assumption that returns to education reflect the labor productivity of graduates, this small difference between the labor market performance of graduates in public and privates does not seem to justify an accusation of low quality in the private sector.
} 
d) Using existing universities to exert quality control over the new privates. Chile is the clearest case, this role being carried out by established universities. The same with Argentina, from the nineties on. Not a clear case of success.

We must recognize that there is a considerable potential for abuse under a full laissez faire regime. This is because, in the low-end institutions, students are not able to find out what is going on. Contrarywise, a heavy handed, controlling approach, can make abuse harder, yet at the cost of prevening institutional innovation and a better adaptation to the variety of existing missions and publics served. Different countries may need to move in opposite directions along this dimension, seeking a better balance ${ }^{21}$.

This essay proposes that neither the usual controls nor neglect are the solution for the lower end of private higher education. Instead, some degree of support for NUIs seems to be in order. Low-end four-year programs, as well as 2-3 year programs, lack technical expertise and can benefit from support, in the form of teacher training and materials. Nevertheless, education authorities have done very little along these lines.

Partial subsidization is indeed a way of giving schools resources, in addition to what relatively poor students can afford to pay in tuition. But this policy deals with only one aspect of the problem. Up to a certain degree, the highly public NUI sector in Mexico offers subsidies to private institutions. However, it is also a good example of institutions becoming too close to the government, with excessive centralized bureaucratic control (KENT, 1996).

In conclusion, a firm case for a stronger presence of the public sector and support for specific activities can be made both on equity and efficiency grounds.

\section{The need for new models}

The main contention of this essay is that the low end of the private education lacks good models and the means to implement them. To emulate the elite institutions is plainly wrong. It perpetuates the mimicry that condemns these institutions to being a pale image of something they cannot become, not only because of economic constraints but also on account of the students to which they cater.

${ }^{21}$ In the case of Brazil, as an example, it would be possible to move away from controlling processes, replacing them with the existing measurements of quality at graduation. Unfortunately, there is some but not much use of performance results in the system, in order to simplify process controls. An extensive discussion of this point is beyond the scope of this article. 
There are, at least, two different models that would be far more appropriate for them. The first, relevant for low-end universities, would be a tuned down and more practical general education program. It is a fact that most of the students will not become economists or psychologists, regardless of the institution they enroll in. However, they can surely benefit from four or five additional years of attending higher education courses. This much is clear. The critical issue is how to target this general education to the scholastic profiles of the real students. We contend that to achieve that, the teaching should be less abstract and less ambitious.

Curricula targeted at levels which are far too high for the real students defeat the objectives of offering a Liberal Education which aims at sharpening analytical skills, enhancing reading comprehension and writing intelligently. This is what prepares the students to learn along their productive lives. One learns how to learn by manipulating ideas, but only if these ideas are mastered rather than memorized. Needless to say, this prescription runs against the grain of Latin American prevailing view of higher education, mandating that all of it has to be lofty teaching and highbrow research.

The second model, relevant for NUI, addresses the technical courses that give the students a high level of specific competence to take up very clearly defined occupations. This is where the American Community Colleges, the French IUTs $^{22}$ and the German Fachhochschulen have excelled and Latin America has not done well.

Being short courses, the close links with the labor market are essential. Either there is a job waiting and the course is a great success or the job is not there and the failure is almost complete. Given the nature of the occupations catered by these courses, specialization is the norm and the number of different programs can be enormous.

In such courses, the balance between theory and practice is delicate and certainly not the same as that observed in conventional four to six year engineering courses. Shorter courses need a strong presence of truly practical subjects, not merely reading textbooks or class notes which describe machines and processes. One learns about air conditioning by fixing or installing them, not by playing with the mathematical equations of thermodynamics. In fact, Mathematics is learned by

\footnotetext{
22 The French government invested heavily in the creation of a network of IUTs. The results of the selection process (the Baccalaureate test) are very revealing. in this regard. The most academically gifted students choose the best public universities. The second tier chooses the IUTs. Those who cannot find the vacancies in them have to go to lesser public universities. In other words, IUTs are a preferred choice for many who want a more applied career.
} 
applying thermodynamic formulae to concrete calculations of air-conditioning systems, rather than by siting in conventional Calculus courses. In other words, short courses need theory, but it should be embedded in practical activities.

Standard economics would lead us to expect the market to adjust. After all, the owners of these schools are supposed to be rational economic operators. They are expected to offer the students the programs that would bring them the best possible job possibilities. If they do it right, they would derive maximum benefits from their investments, since more students would enroll.

Unfortunately, for such matters, the invisible hand is often clumsy or lacks dexterity. In this area, the market either fails or adjusts at an extremely slow pace, entailing considerable costs for all involved, be they students, institutions, or the economy in general. Spontaneous adjustments along these lines are taking place only exceptionally in Latin America ${ }^{23}$.

Worse, ideology remains powerful. Education authorities have a very negative view on anything that is private. This leads to hostility or, in the best of cases, to indifference and inaction, regarding a group of institutions with a very high potential.

Several reasons explain the present difficulties.

- Fragmentation. The majority of these institutions are small or very small. The costs of investing in planning new courses are too high for most. Unfortunately, they have difficulties working collectively, since they may compete for the same market share.

- Limited access to information and intellectual leadership. These schools are owned and operated by people who tend to lack the intellectual stature to conceive new models of courses and programs. Worse, they remain alienated from mainstream thinking about higher education. To wit, they cannot afford to take a plane and visit an excellent school abroad. They are never invited to conferences, seminars or workshops. They have no access to what the educational authorities are thinking or planning. Their access to policy-making circles remain problematic, to say the least.

\footnotetext{
${ }^{23}$ An interesting development in Chile is worth metinging here. Short post-secondary courses started being offered by smallish and impoverished institutions. However, their prestige was so low that they failed to attract the expected students. Progressively, universities of better standing perceived that there was a promising market there and started offering such programs, with much greater success. In so many words, the higher status of universities came to the rescue of these programs.
} 
- Rigidity in curricula and legislation. Very often, official curricula are inflexible and obsolete. Most of the changes required to have high-performance courses in technical areas would collide with the existing legislation and official curricula. There are known loopholes, but these institutions often lack the courage to use them, out of fear of reprisals. They also lack the status and the self-confidence that allows the big and famous institutions to challenge or break the rules with impunity.

- Lack of teaching materials and trained faculty. Creating a different program requires new courses, with their syllabus and requisite teaching materials. This is expensive, beyond the capabilities of the average small technical college. Even if the materials were available abroad, these schools do not have the means to find and translate them. Worse, one can only teach what the available teachers have mastered. New programs would require training teachers with different profiles. Small schools teach whatever can be taught with the teachers they can find in the market.

- Lack of deep pockets to launch new courses with new occupational profiles. In an innovative course, the first promotions will be thin and reticent. The school could hardly break even in a couple of years and these modest operators do not have the financial resources to operate for long on the red.

For all these factors, it is not reasonable to expect these schools to lift themselves by their own bootstraps. In this domain, the free market tends to perpetuate a vicious circle of mimicry and inadequate programs. This is one of the classic cases where the state should intervene to correct structural flaws of the market. But before that, educational authorities should understand the need to take a much closer and attentive look at the particular needs of this segment of higher education. Public policy should single out this low end of higher education as the one in dire need of fresh thinking.

\section{Some conclusions}

The authors believe that the low end of the private higher education sector can perform a valuable social role. After all, they deal with the less academically endowed and the less affluent students to reach post-secondary level. Yet, by itself, the sector is unable to develop the requisite courses, the training materials or the instructors that are required to implement this role. Hence, the participation of the public sector is indispensable.

The lower tier privates need support, at least as much as top quality elite institutions in the region need research grants or first-tier privates need publicly supported student loan schemes. 
The implementation problems of taking seriously this conclusion could be less than trivial. The very nature of many of these institutions, born in no man's land and grown unsupervised could make them a very elusive target, from a policy perspective.

The other side of the equation is also riddled with shortcomings. The institutional weaknesses of the Latin American governments are severe and extend to most countries in the region. Public bureaucracies may not have the capacity to spot the right opportunities for intervention. It makes more sense to focus in programs that provide generic support for initiatives and certain lines of action. Picking this or that institution as the "right" one is far more perilous. Perhaps, general rules that would force institutions to improve themselves as a requirement for support are a good idea. An example along this line of thinking was an Interamerican Development Bank loan to non-university tertiary in Argentina. In order to receive funds for academic improvement, institutions had to associate themselves with business or local governments and prepare joint projects, thus making it more likely that the connection between education and economic needs is right ${ }^{24}$.

Implementation challenges, however, should not deter governments in Latin America from the overdue need to support the academically weaker lower tiers of private higher education. The simple reason is that governments learn by doing. Even if they are clumsy at the beginning, practice tends to improve performance.

\footnotetext{
${ }^{24}$ Although severely downsized as a result of the economic crisis in 2001, the project, known as Presnu, ended up accrediting 17 new technological institutes and 43 new diplomas well attuned to private sector demand for skills. The goal of setting up these new institutions through public/private sector partnerships in the provinces, as well as the goal of managing the licensing and accreditation process with high technical standards and transparency was fully accomplished (BANCO INTERAMERICANO DE DESARROLLO. Informe de terminación de proyecto: programa de reforma de la educación superior técnica no universitaria Argentina. Washington, DC, 2008. [Mimeo].). Several of the institutions originated in the context of this project continue to exists and prosper almost two decades after their inception.
} 


\section{A mão invisível e o ensino superior latinoamericano?}

\section{Resumo}

O ensaio discute os pontos fortes e as fragilidades do ensino superior privado na América Latina, defendendo a posição de que tem um papel importante. Os números sugerem que lucro e qualidade acadêmica não estão correlacionados. No que tange à regulação, defende a posição de que nem liberalidade total e nem controles pesados produzem os resultados esperados. $O$ que as instituições pequenas e modestas precisam é de apoio público para oferecer uma qualidade correta e inovar nos cursos menos tradicionais, como os tecnólogos. De fato, precisam de ajuda para montar os cursos, preparar materiais educativos e treinar os professores.

Palavras-chave: Público. Privado. Educação superior. Universidade. Educação póssecundária. Diversificação. Educação técnica. Lucro. Qualidade. Regulação. Acreditação. Autorização. Treinamento de professores. Materiais de ensino.

\section{La mano invisible y la ensenanza superior latinoamericana}

\section{Resumen}

Este artículo discute las fortalezas y limitaciones de la educación superior privada en América Latina. Argumenta que las instituciones privadas juegan un papel importante y muestra, con cifras, que el lucro y la educación de calidad no están correlacionadas. Al discutir las regulaciones, el artículo sugiere que tanto politicas basadas en fuertes controles, como las que adoptan estrategias extremadamente liberales dejando al mercado que opere por su cuenta, han fallado en producir los resultados esperados. Lo que las instituciones privadas pequeñas y menos ricas necesitan es apoyo público. Esto con la finalidad de ofrecer educación de calidad y de ser capaces de innovar en la forma de cursos no-tradicionales, como en el caso de diplomas cortos en carreras tecnológicas. El apoyo es necesario, de hecho, para estructurar cursos, preparar materiales de enseñanza y entrenar a los profesores.

Palabras clave: Público. Privado. Educación superior. Universidades. Educación postsecundaria. Diversificación. Educación técnica. Lucro. Calidad. Regulación. Acreditación. Autorización. Capacitación docente. Materiales de enseñanza. 


\section{References}

ALBORNOZ, O. La universidad ¿Reforma o experimento? El discurso académico contemporáneo según las perspectivas de los organismos internacionales: los aprendizajes para la universidad venezolana y latinoamericana. Caracas: IESALC, 2013.

BALÁN, J.; GARCÍA DE FANELLI, A. M. El sector privado de la educación superior. In KENT, R. (Org.). Los temas críticos de la educación superior en América Latina. Mexico: Fondo de Cultura Económica, 1997. V. 2.

BERNASCONI, A. El sistema de supervisión y mejoramiento de la calidad de la educación superior de El Salvador: estudio de caso. In: SEMINARIO EDUCACIÓN SUPERIOR Y CIENCIA Y TECNOLOGÍA EN AMÉRICA LATINA Y EL CARIBE: RESPUESTAS FRENTE A LA EXPANSIÓN Y A LA DIVERSIFICACIÓN; 2008; Fortaleza. Fortaleza: Banco Interamericano de Desarrollo, 2008.

BRUNNER, J.; FERRADA, R. (Eds.). Educación superior en Iberoamérica. Providencia: Centro Interuniversitario de Desarrollo, 2011. (Informe 2011).

BRUNNER, J. J.; VILLALOBOS, C. Políticas de educación superior en iberoamérica, 2009-2013. In: ENCUENTRO DE RECTORES UNIVERSIA, 3., 2014; Rio de Janeiro. Santiago: Universidad Diego Portales, 2014. p. 8-37.

BRUNNER, J. J.; WOLFF, L. Higher education in Venezuela: issues and options for reform” In: WOLFF, L.; ALBRECHT , D. (Eds.). Higher education reform in Chile, Brazil and Venezuela. Washington, DC: The World Bank, 1992.

CASTRO, C. M.; GIUNTINI, A.; LIMA, L. Avaliação do ensino superior: acertos e eerrapagens. Abmes Cadernos, v. 22, p. 1-68, 2011.

COX, C. Informe sobre los institutos profesionales. In: LEMAITRE, M. J. (Org.). La educación superior en Chile: un sistema en transición. Santiago: Corporación de Promoción Universitaria, 1990. (Colección Foro de la educación superior).

GARCÍA GUADILLA, C. Situación y principales dinámicas de transformación de la educación superior en América Latina. 2. ed. Caracas: Ediciones CRESALC/UNESCO, 1997. (Colección Respuestas, vol 2).

GUAIPATÍN, C.; SCHWARTZ, L. Ecuador: análisis del Sistema Nacional de Innovación. Washington, DC; Banco Interamericano de Desarrollo, 2014. 
KENT, R. Regulación de la educación superior en México. México, DF:

Asociación Nacional de Universidades e Instituciones de Educación Superior, 1996.

LEVY, D. Building the third sector: Latin America's private research centers and non-profit development. Pittsburgh: University of Pittsburgh Press, 1996.

SAMPAIO, H. O setor privado do ensino superior no Brasil: trajetória e perspectivas. In: ORGANIZACIÓN DE LAS NACIONES UNIDAS PARA LA EDUCACIÓN, LA CIENCIA Y LA CULTURA - UNESCO; INSTITUTO INTERNACIONAL PARA LA EDUCACIÓN SUPERIOR EN AMÉRICA LATINA Y EL CARIBE - IESALC. La educación superior pública y privada en América Latina y el Caribe: contexto de internacionalización y proyecciones de políticas públicas. Caracas: UNESCO/IESALC, 2014.

SANFUENTES, A. Políticas económicas para la universidad. Santiago: Instituto Latinoamericano de Doctrina y Estudios Sociales, 1990.

TRAMONTIN, R.; BRAGA, R. O ensino particular no Brasil: traços de um perfil. In: MENDES, C.; CASTRO, C. M. (Orgs.). Qualidade, expansão e financiamento do ensino superior privado. Brasília, DF: Associação Brasileira de Mantenedoras de Ensino Superior, 1984.

UNITED NATIONS EDUCATIONAL, SCIENTIFIC AND CULTURAL ORGANIZATION - UNESCO. Institute of Statistics. Comparing education statistics across the world. Montreal, 2010. (Global education digest 2010).

.Opportunities lost: the impact of grade repetition and early school leaving. Montreal, 2012. (Global education digest 2012).

URZÚA, S. La rentabilidad de la educación superior en Chile: revisión de las bases de 30 años de políticas públicas. Estudios Públicos, n. 125, p. 1-52, 2012.

\section{Informações dos autores}

Claudio de Moura Castro: Special Advisor to the President of the Positivo Group-PR. Professor Doutor. Contato: claudiodemouracastro@me.com

Juan Carlos Navarro: Works at the Competitiveness and Innovation Division at the Interamerican Development Bank. Professor Doutor. Contato: juancn@iadb.org 